\title{
Effects of protease supplementation on growth performance, blood constituents, and carcass characteristics of growing-finishing pigs
}

\author{
Yejin Min ${ }^{1 \#}$, Yohan Choi ${ }^{1 \#}$, Younghwa Kim ${ }^{1}$, Yongdae Jeong ${ }^{1}$, Doowan Kim ${ }^{1}$, Joeun Kim ${ }^{1}$, Hyunjung Jung ${ }^{1 *}$ \\ and Minho Song ${ }^{*}$
}

${ }^{1}$ Swine Science Division, National Institute of Animal Science, Rural Development Administration, Cheonan 31000, Korea

${ }^{2}$ Department of Animal Science and Biotechnology, Chungnam National University, Daejeon 34134, Korea

\begin{abstract}
This experiment was conducted to evaluate the effects of dietary protease on growth performance, blood constituents, and carcass characteristics of growing-finishing pigs. A total of 48 growing pigs (initial body weight, $34.8 \pm 0.62 \mathrm{~kg}$ ) were randomly assigned to 2 dietary treatments ( 6 pigs/pen; 4 replicates/treatment). The treatments were a diet based on corn and soybean meal (CON) and CON supplemented with $0.01 \%$ of protease (PRO). Pigs were fed respective dietary treatments with a 2-phase feeding program for 12 weeks. Pigs fed PRO had higher average daily gain (ADG; phase I, 866.38 vs. 821.75 $\mathrm{g} / \mathrm{d}$; overall, $910.96 \mathrm{vs.} 866.30 \mathrm{~g} / \mathrm{d} ; p<0.05$ ) and gain to feed ratio (G:F; phase I, $0.345 \mathrm{vs.} 0.363 \mathrm{~g} / \mathrm{g} ; p<0.05$ ) than those fed CON. However, there were no differences on blood constituents and carcass characteristics between CON and PRO of growing-finishing pigs. In conclusion, dietary protease supplementation in the typical diet for growing-finishing pigs improved growth rate.
\end{abstract}

Keywords: Blood constituents, Carcass characteristics, Growing-finishing pigs, Growth performance, Protease

\section{Background}

Soybean meal is one of major ingredients for pigs as a protein source, but it contains several anti-nutritional factors (ANF), such as lectins, oligosaccharides, haemagglutinin, goitrogenic factors, trypsin inhibitors, and antigenic proteins, that cause reduction of protein utilization of pigs by inhibiting the secretion of pancreatic digestive enzymes and increasing the loss of endogenous secretions of pigs [1-4]. These ANFs can be reduced by heat treatment, fermentation process, addition of enzymes, or etc., resulting in improvement of protein utilization of pigs [4,5]. Futhermore, there are two issues in the swine production, such as the increase of feed cost and environmental pollution from undigested protein by pigs. The protein sources including soybean meal in pig diets are relatively expensive compared with other ingredients and thus the unavailable protein by pigs cause the increase of feed cost. The undigested protein by pigs is also related to the environmental pollution by nitrogen emission from pigs [6,7]. Therefore, the swine industry has been looking for the ways to solve these issues.

Addition of dietary protease in pig diets may be one of strat-

\footnotetext{
Received: Jul 9, 2019 Revised: Jul 15,2019 Accepted: Jul 15, 2019

"These authors contributed equally to this work.

"Corresponding author: Minho Song, Department of Animal Science and Biotechnology, Chungnam National University, Daejeon 34134, Korea.

Tel: +82-42-821-5776, E-mail: mhsong@cnu.ac.kr

Hyunjung Jung, Swine Science Division, National Institute of Animal Science, Rural Development Administration, Cheonan 31000, Korea.

Tel: +82-41-580-3452, E-mail: hyjjung@korea.kr
}

This is an Open Access article distributed under the terms of the Creative Commons Attribution Non-Commercial License (http://creativecommons.org/licenses/by$\mathrm{nc} / 4.0 /$ ) which permits unrestricted non-commercial use, distribution, and reproduction in any medium, provided the original work is properly cited.

Copyright (C) 2019 Korean Society of Animal Science and Technology. 
egies to improve nutrient availability and reduce the feed cost in the swine industry. Dietary protease is generally used to reduce the undigested protein and contribute to improvement of nutrient utilization of pigs [8]. However, dietary protease in pig diets has been commonly used as one of enzyme sources for commercially available multi-enzyme products [9-13]. Recently, several studies showed beneficial effects on growth performance, nutrient digestibility, or etc. of pigs fed diets containg dietary protease alone, not multi-enzyme types [14-16], but there was limited evidence for its effects and modes of action. Therefore, the objective of this study was to investigate the effects of dietary protease in on the growth performance, blood constituents, and carcass characteristics of growing-finishing pigs.

\section{Materials and Methods}

The experimental protocol for this research was reviewed and approved by the Institutional Animal Care and Use committee at the National Institute of Animal Science. This experiment was conducted at the facility of National Institute of Animal Science Farm.

\section{Animal and experimental design}

A total of 48 growing pigs [(Landrace $\times$ Yorkshire $) \times$ Duroc; 34.8 $\pm 0.62 \mathrm{~kg}$ of initial body weight (BW); all barrows] were randomly assigned to 2 dietary treatments (6 pigs/pen; 4 replicates/ treatment) in a completely randomized design. The treatments were a diet based on corn and soybean meal (CON) and CON supplemented with $0.01 \%$ of protease (PRO). The protease used in this study was a commercial product (Ronozyme ${ }^{\circledR}$ ProAct, DSM nutrition products, Kaiseraugst, Switzerland) containing 75,000 protease units/g derived from Bacillus licheniformis. The diets were formulated to meet or exceed the nutrient requirements of growing and finishing pigs, estimated by the NRC (2012) (Table 1). The pigs were fed respective dietary treatments with a 2-phase feeding program for 12 weeks. Pigs were housed in conventional facilities with an all-slatted concrete floor $\left(3.2 \times 3.6 \mathrm{~m}^{2}\right)$ and allowed access to diets and water during the overall experimental period.

\section{Data and sample collection and measurement}

The pig BW and feed intake were recorded at the starting day and end of each phase. Average daily gain (ADG), average daily feed intake (ADFI) and gain to feed ratio (G:F) were calculated. Blood samples were collected from the jugular vein of 8 pigs per treatment using $8 \mathrm{~mL}$ EDTA tubes. The blood samples were analyzed to measure number of white blood cells and proportions of their differentiation using a multi-parameter automated hematology analyzer calibrated for porcine blood (Hemavet 950FS, Drew Scientific, UK).
Table 1. Composition of basal diets for phase I and II (as-fed basis)

\begin{tabular}{|c|c|c|}
\hline Items & Phase I (grower) & Phase II (finisher) \\
\hline Ingredient (\%) & 100.00 & 100.00 \\
\hline Corn $(7.2 \%)$ & 62.83 & 62.66 \\
\hline Soft wheat $(11.5 \%)$ & - & 11.00 \\
\hline Soybean meal (45\%) & 28.35 & 19.72 \\
\hline Animal fat & 3.07 & 1.84 \\
\hline Molasses & 3.00 & 3.00 \\
\hline Mono-dicalcium phosphate & 0.62 & 0.27 \\
\hline Lime stone & 1.04 & 0.86 \\
\hline Salt & 0.30 & 0.30 \\
\hline L-Lysine (98\%) & 0.25 & 0.02 \\
\hline DL-Methionine (98\%) & 0.06 & - \\
\hline L-Tryptophan (20\%) & 0.15 & - \\
\hline Choline-chloride (50\%) & 0.05 & 0.05 \\
\hline Phytase & 0.05 & 0.05 \\
\hline Vitamin-mineral premix ${ }^{1)}$ & 0.23 & 0.23 \\
\hline \multicolumn{3}{|l|}{ Calculated chemical composition } \\
\hline Metabolizable energy (kcal/kg) & $3,300.00$ & $3,300.00$ \\
\hline Crude protein (\%) & 18.00 & 15.00 \\
\hline Total calcium (\%) & 0.59 & 0.45 \\
\hline Total phosphorus (\%) & 0.50 & 0.41 \\
\hline SID Lysine (\%) & 0.89 & 0.66 \\
\hline SID Methionine (\%) & 0.34 & 0.25 \\
\hline SID Methionine + Cysteine (\%) & 0.65 & 0.53 \\
\hline SID Tryptophan (\%) & 0.19 & 0.13 \\
\hline
\end{tabular}

${ }^{11}$ The vitamin-mineral premix provided the following quantities of vitamins and minerals per kilogram of diets: vitamin $A, 10,000 \mathrm{IU}$; vitamin $\mathrm{D}_{3}, 2,000 \mathrm{IU}$; vitamin $\mathrm{E}, 250 \mathrm{IU}$; vitamin $\mathrm{K}_{3}, 0.5 \mathrm{mg}$; vitamin $\mathrm{B}_{1}, 0.49 \mathrm{mg}$ as mononitrate; thiamin, $0.49 \mathrm{mg}$ as thiamin mononitrate; riboflavin, $1.50 \mathrm{mg}$; pyridoxine, $1 \mathrm{mg}$ as pyridoxine hydrochloride; vitamin $B_{12}, 0.01 \mathrm{mg}$; niacin, $10 \mathrm{mg}$ as nicotinic acid; pantothenic acid, $5 \mathrm{mg}$ as calcium pantothenate; folic acid, $1 \mathrm{mg}$; biotin as d-biotin, $0.1 \mathrm{mg}$; choline, $125 \mathrm{mg}$ as choline-chloride; $\mathrm{Mn}, 60 \mathrm{mg}$ as manganese sulfate; $\mathrm{Zn}, 75 \mathrm{mg}$ as zinc sulfate; $\mathrm{Fe}, 20 \mathrm{mg}$ as ferrous sulfate; $\mathrm{Cu}, 3 \mathrm{mg}$ as cupric sulfate; $\mathrm{I}, 1.25 \mathrm{mg}$ as calcium iodate; $\mathrm{Co}, 0.5$ $\mathrm{mg}$ as cobaltous carbonate; and $\mathrm{Mg}, 10 \mathrm{mg}$ as magnesium oxide.

\section{Slaughter and carcass evaluation}

After completion of the finishing period, pigs fed experimental diets until slaughtered. Approximately four hours before transport, feed was withdrawn. The live BW of finishing pigs used in the experiments was recorded before slaughter. To reduce stress, the pigs were showered with water, and water was freely available for drinking during lairage. The pigs were rested for about eight hours. Pigs were slaughtered according to industry accepted procedures (Korea Institute for Animal Products Quality Evaluation). The final live BW of pigs was recorded, and then they were slaughtered through electrical stunning and scalding-singeing. The hot carcass weight (HCW) was recorded, and dressing percentage was calculated by comparing final live BW and HCW. After splitting, the back fat 
depth at the $11^{\text {th }}$ and $12^{\text {th }}$ thoracic vertebra and between the last thoracic vertebra and the $1^{\text {st }}$ lumbar vertebra was measured.

\section{Statistical analysis}

Data were analyzed with the PROC GLM procedure of SAS (SAS Inst. Inc., Cary, NC, USA) in the completely randomized design. The experimental unit was the pen. The statistical model for growth performance, blood constituents, and carcass characteristics included dietary treatments as the fixed effect and initial BW as the covariate. Results are presented as a mean \pm SEM. Statistical significance and tendency were considered at $p<0.05$ and $0.05 \leq p$ $<0.10$, respectively.

\section{Results and Discussion}

Pigs fed PRO had higher ADG $(p<0.05)$ during phase I and overall experimental period and gain to feed ratio $(p<0.05)$ during phase I than those fed CON, but there was no difference on ADFI of pigs between CON and PRO (Table 2). Most previous studies also showed that pigs fed diets with dietary protease had higher growth rate of pigs than those fed diets without dietary protease [14-17]. However, other research reported that addition of dietary protease in pig diets did not improved growth rate [18-20]. The reason for the positive effect of dietary protease on growth rate

Table 2. Effects of dietary protease on growth performance of growing-finishing pigs ${ }^{1)}$

\begin{tabular}{lrrrr}
\hline \multicolumn{1}{c}{ Items ${ }^{2}$ ) } & \multicolumn{1}{c}{ CON } & \multicolumn{1}{c}{ PRO } & SEM & $p$-value \\
\hline Phase I (1-60 d) & & & & \\
Initial BW (kg) & 34.93 & 34.67 & 0.62 & 0.770 \\
Final BW (kg) & 84.23 & 86.65 & 1.07 & 0.117 \\
ADG (g/d) & 821.75 & 866.38 & 12.01 & 0.012 \\
ADFI (g/d) & $2,380.48$ & $2,388.60$ & 20.79 & 0.834 \\
G:F (g/g) & 0.345 & 0.363 & 0.01 & 0.020 \\
\hline Phase II (61-88 d) & & & & \\
Final BW (kg) & 111.16 & 114.83 & 1.59 & 0.108 \\
ADG (g/d) & 961.77 & $1,006.49$ & 27.55 & 0.257 \\
ADFI (g/d) & $3,110.12$ & $3,216.52$ & 77.21 & 0.417 \\
G:F (g/g) & 0.311 & 0.313 & 0.01 & 0.873 \\
\hline Overall (1-88 d) & & & & \\
Initial BW (kg) & 34.93 & 34.67 & 0.62 & 0.770 \\
Final BW (kg) & 111.16 & 114.83 & 1.59 & 0.108 \\
ADG (g/d) & 866.30 & 910.96 & 14.36 & 0.033 \\
ADFI (g/d) & $2,745.30$ & $2,802.56$ & 41.66 & 0.395 \\
G:F (g/g) & 0.316 & 0.325 & 0.01 & 0.273 \\
\hline
\end{tabular}

${ }^{1)}$ Each value is the mean value of 4 replicates (6 pigs/pen).

${ }^{2)} \mathrm{CON}$, basal diet; PRO, $\mathrm{CON}+0.01 \%$ protease; $\mathrm{BW}$, body weight; $\mathrm{ADG}$, average daily gain; ADFI, average daily feed intake; G:F, gain to feed ratio; SEM, standard error of means. may be related to the improvement of nutrient digestibility and utilization from more hydrolysis of protein by addition of dietary protease in pig diets [21-24].

Addition of dietary protease in the pig diet did not modulate blood constituents of pigs (Table 3). These results were similar to the results reported by Tactacan et al. [24]. The blood constituents measured in this experiment were the total number of white blood cell and its differentiation, such as neutrophils, lymphocytes, monocytes, eosinophils, and basophils, that can be used as indicators for inflammation or immunity [25-27]. The modification of indicators for immunity by some changes of pig diet formula may not be easy in normal conditions of pigs and environment. During the whole experimental period of this experiment, pigs and environmental conditions were normal and thus the blood constituents of pigs may not be changed by addition of dietary protease in pig diets in this experiment. In addition, there were no differences on carcass characteristics among dietary treatments (Table 4). These results were similar to the results of previous studies [16,28,29], but Wang et al. [30] showed addition of dietary protease in the pig diet changed carcass characteristics of pigs. However, further investigation is needed to clarify the effects of dietary protease on the blood constituents and carcass characteristics of growing-finishing pigs.

Table 3. Effects of dietary protease on complete blood count of growing-finishing pigs ${ }^{1)}$

\begin{tabular}{lrrrr}
\hline \multicolumn{1}{c}{ Items $\left.{ }^{2}\right)$} & CON & PRO & SEM & $p$-value \\
\hline Phase I $(60 \mathrm{~d})$ & & & & \\
RBC $\left(\times 10^{6} / \mu \mathrm{L}\right)$ & 7.54 & 7.43 & 0.16 & 0.661 \\
WBC $\left(\times 10^{3} / \mu \mathrm{L}\right)$ & 18.77 & 20.14 & 1.47 & 0.582 \\
NE (\%) & 33.69 & 30.67 & 1.81 & 0.303 \\
LY (\%) & 58.04 & 60.90 & 1.86 & 0.329 \\
MO (\%) & 5.85 & 5.57 & 0.38 & 0.620 \\
EO (\%) & 2.33 & 2.79 & 0.27 & 0.280 \\
BA (\%) & 0.10 & 0.07 & 0.05 & 0.728 \\
\hline Phase II $(88 \mathrm{~d})$ & & & & \\
RBC (× $\left.10^{6} / \mu \mathrm{L}\right)$ & 7.25 & 7.36 & 0.19 & 0.701 \\
WBC $\left(\times 10^{3} / \mu \mathrm{L}\right)$ & 21.50 & 21.93 & 1.43 & 0.845 \\
NE (\%) & 30.49 & 27.36 & 2.33 & 0.390 \\
LY (\%) & 58.39 & 61.93 & 2.16 & 0.307 \\
MO (\%) & 7.33 & 6.70 & 0.59 & 0.495 \\
EO (\%) & 3.71 & 3.60 & 0.32 & 0.807 \\
BA (\%) & 0.09 & 0.04 & 0.03 & 0.227 \\
\hline
\end{tabular}

${ }^{11}$ Each value is the mean value of 4 replicates (6 pigs/pen).

${ }^{2)} \mathrm{CON}$, basal diet; PRO, CON $+0.01 \%$ protease; RBC, red blood cell; WBC, white blood cell; NE, neutrophil; MO, monocyte; BO, eosinophil; BA, basophil; SEM, standard error of means. 
Table 4. Effects of dietary protease on carcass characteristics of finishing pigs ${ }^{1)}$

\begin{tabular}{lrrrc}
\hline \multicolumn{1}{c}{ Items $^{2)}$} & \multicolumn{1}{c}{ CON } & \multicolumn{1}{c}{ PRO } & SEM & p-value \\
\hline Live weight $(\mathrm{kg})$ & 117.05 & 117.42 & 1.84 & 0.890 \\
Hot carcass weight $(\mathrm{kg})$ & 84.85 & 84.82 & 1.50 & 0.990 \\
Dressing percentage $(\%)$ & 72.49 & 72.21 & 0.33 & 0.556 \\
Backfat thickness $(\mathrm{mm})$ & 27.00 & 25.55 & 1.47 & 0.491 \\
Carcass grade & 1.54 & 1.73 & 0.24 & 0.587
\end{tabular}

${ }^{1)}$ Each value is the mean value of 4 replicates (6 pigs/pen).

${ }^{2)} \mathrm{CON}$, basal diet; $\mathrm{PRO}, \mathrm{CON}+0.01 \%$ protease; Based on a scale with 1 , grade $2 ; 2$, grade $1 ; 3$, grade $1^{+} ;$SEM, standard error of means.

\section{Conclusion}

The present study showed addition of dietary protease in the pig diet improved growth rate of growing-finishing pigs, but did not affect their blood constituents and carcass characteristics.

\section{Competing interests}

No potential conflict of interest relevant to this article was reported.

\section{Funding sources}

This work was carried out with the support of "Cooperative Research Program for Agriculture Science and Technology Development (Project No. PJ01161703)" Rural Development Administration, Korea

\section{Acknowledgements}

Not applicable.

\section{Availability of data and material}

Upon reasonable request, the datasets of this study can be available from the corresponding author.

\section{Authors' contributions}

Conceptualization: Kim YH, Jeong YD.

Data curation: Choi YH, Song MH.

Formal analysis: Choi $\mathrm{YH}$.

Methodology: Jeong YD.

Software: Kim DW, Kim JW.

Validation: Jung HJ.

Investigation: Jeong YD, Min YJ.

Writing - original draft: Min YJ.

Writing - review \& editing: Song MH, Jung HH, Choi YH.

\section{Ethics approval and consent to participate}

This study was approved by IACUC of Rural Development Administration (No. NIAS-2019-374).

\section{ORCID}

Yejin Min

Yohan Choi

Younghwa Kim

Yongdae Jeong

Doowan Kim

Joeun Kim

Hyunjung Jung

Minho Song

\section{References}

1. Huisman J,Jansman AJM. Dietary effects and some analytical aspects of antinutritional factors in peas (Pisum sativum), common beans (Phaseolus vulgaris) and soyabeans (Glycine max) in monogastric farm animals. Nutr Abstr Rev. 1991;61:90121.

2. Tamminga S, Schulze H, Van Bruchem J, Huisman J. The nutritional significance of endogenous $n$-losses along the gastrointestinal tract of farm animals. Arch fur Tierernahr. 1995;48:9-22.

3. Raemaekers RH. Crop production in tropical Africa. Brussels, Belgium: DGIC; 2001.p.809-28.

4. Nsoh A. Growth performance, blood profile and carcass characteristics of growing pigs fed diets containing varying levels of soybean milk residue (SBMR). http://hdl.handle. net/123456789/5322. Accessed 10 Aug 2013.

5. Caine WR, Tamminga S, Verstegen MW, Sauer WC, Schulze $\mathrm{H}$. Endogenous recoveries and true ileal digestibilities of amino acids in newly weaned pigs fed diets with protease-treated soybean meal.J Anim Sci. 1997;75:2970-9.

6. Mackie RI, Stroot PG, Varel VH. Biochemical identification and biological origin of key odor components in livestock waste. J Anim Sci. 1998;76:1331-42.

7. Sutton AL, Kephart KB, Verstegen MWA, Canh TT, Hobbs PJ. Potential for reduction of odorous compounds in swine manure through diet modification.J Anim Sci. 1999;77:430-9.

8. Adeola O, Cowieson AJ. Opportunities and challenges in using exogenous enzymes to improve non-ruminant animal production.J Anim Sci. 2011;89:3189-218.

9. Yin YL, Baidoo SK, Jin LZ, Liu YG, Schulze H, Simmins $\mathrm{PH}$. The effect of different carbohydrase and protease supplementation on apparent (ileal and overall) digestibility of nutrients of five hulless barley varieties in young pigs. Livest Prod Sci. 2001;71:109-20.

10. Omogbenigun FO, Nyachoti CM, Slominski BA. Dietary supplementation with multienzyme preparations improves nutrient utilization and growth performance in weaned pigs. J 
Anim Sci. 2004;82:1053-61.

11. Yin YL, Deng ZY, Huang HL, Li TJ, Zhong HY. The effect of arabinoxylanase and protease supplementation on nutritional value of diets containing wheat bran or rice bran in growing pig. J Anim Feed Sci, 2004;13:445-61.

12. Ji F, Casper DP, Brown PK, Spangler DA, Haydon KD, Pettigrew JE. Effects of dietary supplementation of an enzyme blend on the ileal and fecal digestibility of nutrients in growing pigs. J Anim Sci. 2008;86:1533-43.

13. Jo JK, Ingale SL, Kim JS, Kim YW, Kim KH, Lohakare JD, et al. Effects of exogenous enzyme supplementation to corn- and soybean meal-based or complex diets on growth performance, nutrient digestibility, and blood metabolites in growing pigs. J Anim Sci. 2012;90:3041-8.

14. Upadhaya SD, Yun HM, Kim IH. Influence of low or high density corn and soybean meal-based diets and protease supplementation on growth performance, apparent digestibility, blood characteristics and noxious gas emission of finishing pigs. Anim Feed Sci Technol. 2016;216:281-7.

15. Zuo J, Ling B, Long L, Li T, Lahaye L, Yang C, et al. Effect of dietary supplementation with protease on growth performance, nutrient digestibility, intestinal morphology, digestive enzymes and gene expression of weaned piglets. Anim Nutr. 2015;1:276-82.

16. Choe J, Kim KS, Kim HB, Park S, Kim J, Kim S, et al. Effect of protease on growth performance and carcass characteristics of growing-finishing pigs. S Afr J Anim Sci. 2017;47:697-703.

17. Kong C, Park CS, Kim BG. Effects of an enzyme complex on in vitro dry matter digestibility of feed ingredients for pigs. SpringerPlus. 2015;4:261.

18. O'Shea CJ, Mc Alpine PO, Solan P, Curran T, Varley PF, Walsh AM, et al. The effect of protease and xylanase enzymes on growth performance, nutrient digestibility, and manure odour in grower-finisher pigs. Anim Feed Sci Technol. 2014;189:88-97.

19. Mc Alpine PO, O'shea CJ, Varley PF, O'Doherty JV. The effect of protease and xylanase enzymes on growth performance and nutrient digestibility in finisher pigs. J Anim Sci. 2012;90:375-7.

20. Thacker PA. Effect of xylanase and protease on the perfor- mance of growing-finishing pigs fed corn-based diets. J Appl Anim Res. 2015;28:17-23.

21. Guggenbuhl P,Wach Y,Wilson JW. Effects of dietary supplementation with a protease on the apparent ileal digestibility of the weaned piglet. J Anim Sci. 2012;90:152-4.

22. O'Doherty JV, Forde S. The effect of protease and $\alpha$-galactosidase supplementation on the nutritive value of peas for growing and finishing pigs. Irish J Agri Food Res. 1995;38:217-26.

23. Tactacan GB, Cho SY, Cho JH, Kim IH. Performance responses, nutrient digestibility, blood characteristics, and measures of gastrointestinal health in weanling pigs fed protease enzyme. Asian-Australas J Anim Sci. 2016;29:998-1003.

24. Cowieson AJ, Roos FF. Bioefficacy of a mono-component protease in the diets of pigs and poultry: a meta-analysis of effect on ileal amino acid digestibility. J Appl Anim Nutr. 2013;2:e13.

25. Lichtman M, Beutler E, Kipps T, Seligsohn U, Kaushansky K, Prchal J. Williams hematology. 8th ed. New York, NY: McGraw-Hill; 2010. p.823-39.

26. Islam MA, Grobe-Brinkhaus C, Proll MJ, Uddin MJ, Rony SA, Tesfaye D, et al. Deciphering transcriptome profiles of peripheral blood mononuclear cells in response to PRRSV vaccination in pigs. BMC genomics. 2016;17:641.

27. Dubreuil P, Couture Y, Farmer C, Petitclerc D. Hematological and biochemical changes following an acute stress in control and somatostatin-immunized pigs. Can J Anim Sci. 1993;73:241-52.

28. Choe J, Kim KS, Kim HB, Park S, Kim J, Kim S, et al. Effects of protease on growth performance and carcass characteristics of growing-finishing pigs. S Afr J Anim Sci. 2017;47:697-703.

29. Stephenson EW, DeRouchey JM, Escobar J, Woodworth J, Tokach MD, Goodband RD, et al. Effects of a novel protease enzyme (CIBENZA DP100) on finishing pig growth performance and carcass characteristics. Kans Agric Exp Stn Res Rep. 2014;69-76.

30. Wang D, Piao XS, Zeng ZK, Lu T, Zhang Q, Li PF, et al. Effects of keratinase on performance, nutrient utilization, intestinal morphology, intestinal ecology and inflammatory response of weaned piglets fed diets with different levels of crude protein. Asian-Australas J Anim Sci. 2011;24:1718-28. 